\title{
RESEARCH PAPER \\ Production of Sunflower Oil in Response to Nitrogen Fertilization under Semiarid Conditions under Irrigation
}

\author{
Almir Rogerio E. de Souza ${ }^{1}$, Francilene de L. Tartaglia ${ }^{1}$, Allysson P. dos \\ Santos $^{2}$, Fernando S. de Oliveira ${ }^{2}$, Manoel G. dos Santos ${ }^{2}$, Francisco Bezerra \\ Neto $^{2}$, Lindomar Maria da Silveira ${ }^{2}$, and Aurélio P. Barros Júnior ${ }^{2}$ \\ ${ }^{1}$ Federal Institute of Education, Science and Technology of Alagoas (IFAL), Piranhas Campus. Av. Sergipe, \\ S/N - Bairro Xingó, Piranhas-AL, CEP: 57460-000, Brazil. \\ ${ }^{2}$ Federal Rural University of Semiarid (UFERSA), Department of Agrarian and Forest Sciences, Fitotecnia. \\ Av. Francisco Mota, 572 - Bairro Costa e Silva, Mossoró-RN, CEP: 59.625-900, Brazil.
}

\begin{abstract}
A.R.E. de Souza, F. de L. Tartaglia, A.P. dos Santos, F.S. de Oliveira, M.G. dos Santos, F. Bezerra Neto², L.M. da Silveira, and A.P. Barros Júnior. 2021. Production of Sunflower Oil in Response to Nitrogen Fertilization under Semiarid Conditions under Irrigation. Int. J. Agric. Nat. Resour. 57-69. Sunflower is one of the most important oilseeds in the world, whose achenes are valued in several industrial chains, mainly for the extraction and processing of its oil. Although there is some information in the literature, the nitrogen $(\mathrm{N})$ requirements for sunflower in semiarid conditions under irrigation are not yet clear. The experimental design used randomized blocks, with treatments in subdivided plots with four replications during two agricultural seasons. The $\mathrm{N}$ doses (e.g., $0,30,60,90$ and $120 \mathrm{~kg} \mathrm{ha}^{-1}$ ) were assigned to the plots, and to the four sunflower cultivars used (e.g., Aguará 06, Altis 99, Multissol and BRS 122), which were planted in the subplots. The $\mathrm{N}$ doses for the maximum achene yields for the Multissol and BRS 122 cultivars were 81.8 and $86.6 \mathrm{~kg} \mathrm{ha}^{-1}$, respectively, while $\mathrm{N}$ doses of $120 \mathrm{~kg} \mathrm{ha}^{-1}$ produced the maximum achene yields for the Altis 99 and Aguará 06 cultivars in the 2016 crop season. In 2017, the Multissol and BRS 122 cultivars were given N doses of 100.7 and $92.8 \mathrm{~kg} \mathrm{ha}^{-1}$, respectively, and the Altis 99 and Aguará 06 cultivars were each given an $\mathrm{N}$ dose of $120 \mathrm{~kg} \mathrm{ha}^{-1}$ of $\mathrm{N}$. The fertirrigated doses of maximum economic efficiency of $\mathrm{N}$ were 60 and $70 \mathrm{~kg} \mathrm{ha}^{-1}$ for the Multissol and BRS 122 cultivars, respectively. For the oil yields, the maximum $\mathrm{N}$ doses of 78.0 and $86.7 \mathrm{~kg} \mathrm{ha}^{-1}$ for the BRS 122 and Aguará 06 cultivars and for the Multissol and Altis 99 cultivars at an $\mathrm{N}$ dose of $120 \mathrm{~kg} \mathrm{ha}^{-1}$ were used for the 2016 harvest. In 2017, the BRS 122 and Multissol cultivars received N doses of 88.6 and $99.1 \mathrm{~kg}$ $\mathrm{ha}^{-1}$, respectively, and the Altis 99 and Aguará 06 cultivars received $\mathrm{N}$ doses of $120 \mathrm{~kg} \mathrm{ha}^{-1}$. The use of fertigation allowed greater efficiency for the $\mathrm{N}$ doses in the sunflower cultivars in the semiarid region.
\end{abstract}

Keywords: Biofuels, Helianthus annuus L., nitrogen fertigation, oil productivity.

Received Apr 17, 2019. Accepted Jul 26, 2021

Corresponding author: aurelio.barros@ufersa.edu.br 


\section{Introduction}

Sunflower (Helianthus annuus L.) is an industrial crop that has great demand for its edible oil, by the pharmaceutical, chemical and cosmetic industries, and for the production of biofuels, and plays an important role in the world economy (USDA, 2021).

The growing demand for the oil and its derivatives has favored the expansion of sunflower crops in several regions of the world, many of which have semiarid climates (Li et al., 2017). In the Brazilian semiarid region, the expansion of this oilseed crop has seen a special focus in recent years, mainly after being inserted into the national energy matrix through the National Biodiesel Production and Use Program (Cavalcante Júnior et al., 2013; Soares et al., 2020).

Sunflower has unique characteristics, namely, its wide adaptability to various soils and climatic conditions, rapid development cycle, nutrient cycling and high oil content in its achenes are factors that favor the use of this culture in semiarid conditions, and rainfed and irrigated cultivation (Feitosa et al., 2016; Souza et al., 2020).

However, the oil contents and the productivity of the achenes in sunflower crops are factors that dependent on the cultivars and their interactions with the environment. Climate factors such as air temperature, solar radiation and rainfall influence achene filling and the total crop cycle (Li et al., 2017; Demir, 2020).

The highest sunflower yields were obtained by selecting those cultivars that were more adapted to the growing region and an adequate nutritional balance in the soil for cultivation. These factors (e.g., cultivars x nutrition) are directly linked and usually result in the success or other results for sunflower cultivation worldwide (Castro \& Leite, 2018).

For the nutritional balance, adequate nitrogen fertilization is fundamental for sunflower crops. Nitrogen is one of the elements that is most re- quired by cultures because it actively participates in the synthesis of organic compounds that form plant structures, such as amino acids, proteins, nucleic acids and chlorophyll molecules (Taiz et al., 2017).

An $\mathrm{N}$ deficiency in sunflower crops causes nutritional disorders, which affect metabolic and physiological functions, whereas excess $\mathrm{N}$ levels lead to decreased oil contents and increase the incidence of pests and diseases, economic loss and environmental order (Biscaro et al., 2008).

Adequate $\mathrm{N}$ concentrations in soil and plants reflect the important agronomic parameters in sunflower crops, such as the chapter diameters, number and mass of achenes, leaf areas, photosynthesis, oil contents and productivity (Lazicki \& Geisseler, 2016; Silva et al., 2017; Eltarabily et al., 2019).

Therefore, it is essential to determine the ideal $\mathrm{N}$ dose to be used in cultivation, since new demanding and productive cultivars are available on the market, and these require adequate nutrition for their vegetative growth and productive responses (Alves et al., 2017).

Several authors have cited the importance of nitrogen fertigation for the production of achenes and for the oil contents of sunflower crops (Graham \& Varco, 2017; Schultz et al., 2018). However, few studies have elucidated the production performance of sunflower cultivars that were fertilized with $\mathrm{N}$ in tropical semiarid northeastern agricultural crops under irrigation.

The objective of this work was to evaluate the contents and oil yields of sunflower achenes that were fertigated with $\mathrm{N}$ doses in two agricultural crops under semiarid conditions.

\section{Material and methods}

The experiments were conducted in two agricultural crops in the months of February-May 
2016 and 2017 at the Experimental Farm Rafael Fernandes ( $5^{\circ} 03^{\prime} \mathrm{S}$ and $37^{\circ} 23^{\prime} \mathrm{W}$ at $18 \mathrm{~m}$ altitude), which belongs to the Federal Rural University of Semi-Arid University (UFERSA), which is located in the municipality of Mossoró-RN. The climatic classification according to Köppen (1936) is BShw, tropical semiarid very hot and dry, with two dominant seasons: rainy, usually in the months of February to May and with drought from June to January, with an average temperature of $27.4{ }^{\circ} \mathrm{C}$ and a mean rainfall amount of 673.9 mm (Espínola Sobrinho et al., 2011). The average meteorological data and phenological phases of the experimental period are shown in Figure 1.
The soil was classified as a Red Yellow Distrophic Latosol, loam-sand textural class, with the following physical characteristics: coarse sand = $660 \mathrm{~g} \mathrm{~kg}^{-1}$, fine sand $=220 \mathrm{~g} \mathrm{~kg}^{-1}$, silt $=20 \mathrm{~g} \mathrm{~kg}^{-1}$ and clay $=100 \mathrm{~g} \mathrm{~kg}^{-1}$. The results of the chemical analyses after liming in the 2016 harvest: $\mathrm{pH}$ in $\mathrm{H}_{2} \mathrm{O}(1: 2.5)=5.9$; organic matter (O.M.) $=7.52 \mathrm{~g}$ $\mathrm{kg}^{-1} ; \mathrm{N}=0.42 \mathrm{~g} \mathrm{~kg}^{-1} ; \mathrm{P}=2.21 \mathrm{mg} \mathrm{dm}{ }^{-3} ; \mathrm{K}^{+}=27.1$ $\mathrm{mg} \mathrm{dm}{ }^{-3} ; \mathrm{Ca}^{2+}=0.40$ cmolc dm $\mathrm{dm}^{-3} ; \mathrm{Mg}^{2+}=0.57$ cmolc $\mathrm{dm}^{-3}$, and $\mathrm{Al}^{3+}=0.0 \mathrm{cmolc} \mathrm{dm}^{-3}$. For the 2017 crop harvest: $\mathrm{pH}$ in $\mathrm{H}_{2} \mathrm{O}(1: 2.5)=5.8$, O.M. $=4.38 \mathrm{~g} \mathrm{~kg}^{-1}, \mathrm{~N}=0.32 \mathrm{~g} \mathrm{~kg}^{-1}, \mathrm{P}=1.9 \mathrm{mg} \mathrm{dm}{ }^{-3}, \mathrm{~K}^{+}$ $=32.4 \mathrm{mg} \mathrm{dm}^{-3}, \mathrm{Ca}^{2+}=1.40 \mathrm{cmolc} \mathrm{dm}{ }^{-3}, \mathrm{Mg}^{2+}=$ $0.70 \mathrm{cmolc} \mathrm{dm}^{-3}$, and $\mathrm{Al}^{3+}=0.0 \mathrm{cmolc} \mathrm{dm}{ }^{-3}$.
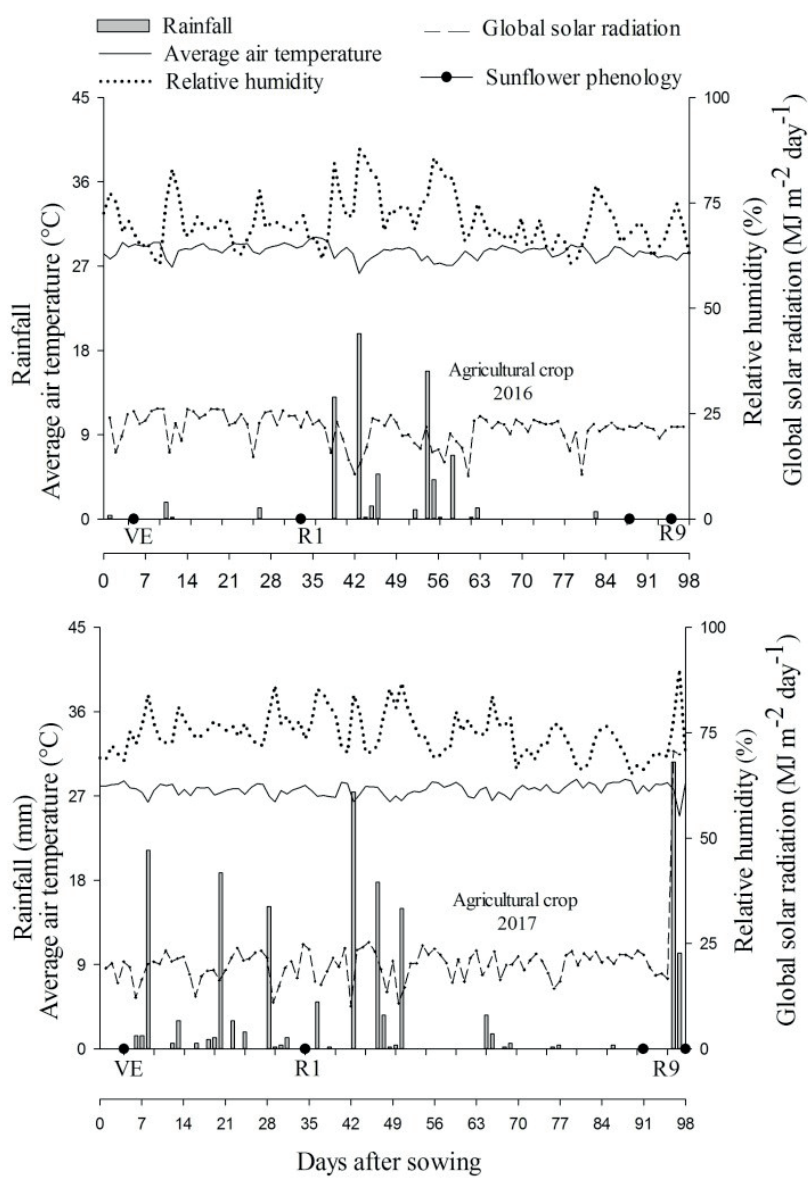

Figure 1. Mean values of daily rainfall $(\mathrm{mm})$, mean air temperature $\left({ }^{\circ} \mathrm{C}\right)$, relative air humidity $(\%)$, global solar radiation $\left(\mathrm{MJ} \mathrm{m}^{-2}\right.$ day $^{-1}$ ) and phenological phases (emergent - VE, reproductive stage - R1 and harvest - R9) that correspond to the months of February to May for the agricultural crops of 2016 and 2017. 
The experimental design consisted of randomized blocks, with treatments in subdivided plots with four replications. $\mathrm{N}$ doses of $0,30,60,90$ and $120 \mathrm{~kg} \mathrm{ha}^{-1}$ were assigned to the plots, and the four sunflower cultivars (e.g., Aguará 06, Altis 99, Multissol and BRS 122) were planted in the subplots.

The soil preparation consisted of plowing, harrowing and liming and after 45 days, fertilization of the foundation was carried out based on the soil analysis and according to the recommendations for the use of correctives and fertilizers in Minas Gerais (Ribeiro et al., 1999). The N source used was urea, which was supplied via irrigation water, by using a bypass tank that was constructed of PVC pipe. Fertirrigations with $\mathrm{N}$ were applied $1 / 3$ at sowing and $2 / 3$ split in the reproductive phase $\mathrm{R} 1$, with the appearance of small floral buds at the apex and R3, when the floral bud elongation was at a distance greater than $2.0 \mathrm{~cm}$ above the last leaf. The parceling of the $\mathrm{N}$ doses corresponded to the treatments.

Phosphorus was applied in the form of a single superphosphate application, $70 \mathrm{~kg} \mathrm{ha}^{-1} \mathrm{P}_{2} \mathrm{O}_{5}$, in the sowing holes during the fertilization of the foundation. Potassium in the form of $\mathrm{KCl}, 70 \mathrm{~kg}$ $\mathrm{ha}^{-1} \mathrm{~K}_{2} \mathrm{O}$, was applied via fertigation according to the $\mathrm{N}$ applications.

The plots were composed of four plant lines with spacings of $0.7 \mathrm{~m}$ between the rows and $0.3 \mathrm{~m}$ between the plants, with total areas of $12.6 \mathrm{~m}^{2}$. The harvested area consisted of the two central lines, and one plant at each end of the lines was discarded.

The main agronomic characteristics of the cultivars are as follows: Aguará 06 has a harvest cycle of 110 to 120 days and has striated achenes with oil contents between 44 and 49\%. Altis 99 has a harvest point of 110 to 125 days and has black achenes with oil contents between 43 and 50\%, and both were provided by Atlântica Sementes ${ }^{\circledR}$. The Multissol cultivar has a cycle of 115 to 130 days and has black achenes with white stripes with oil contents between 39 and 50\% and was developed by the Coordination of Integral Technical Assistance (CATI). The BRS 122 cultivar has a cycle of 85 to 100 days with black achenes with gray stripes and oil contents between 40 and 44\% and was developed by Embrapa.

The irrigation system used drip irrigation, with a spacing of $0.3 \mathrm{~m}$ between emitters and an average flow of $1.5 \mathrm{~L} \mathrm{~h}^{-1}$ and used a daily irrigation sheet, while the rainfall and crop evapotranspiration (mm) levels in the phenological phases were considered. The total rainfall accumulations during the phenological cycles of the sunflower crops were $73 \mathrm{~mm}$ in 2016 and $188.4 \mathrm{~mm}$ in 2017.

Sunflower sowing of the first agricultural crop was carried out on February 23, 2016, while the second sowing on February 24, 2017 was performed manually at a depth of 4 centimeters, and 3 seeds per hole were used. Thinning was performed 10 days after sowing, and one plant per hole was retained.

In 2016, harvesting was carried out at the R9 phenological stage, which corresponded to 88 days after sowing (DAS) for the BRS 122 and Multissol cultivars and to 95 DAS for the Altis 99 and Aguará 06 cultivars. In 2017, harvesting was carried for the BRS 122 and Multissol cultivars at 90 DAS and at 98 DAS for the Altis 99 and Aguará 06 cultivars, that is, when the bracts, chapters and stems presented as physical characteristics, with dark brown coloring and moisture contents in the achenes of approximately 14 to $18 \%$.

The harvesting, trials and cleaning of the achenes were performed manually. The characteristics evaluated were a) diagnostic leaves: 28 leaves per plot were collected, and the fifth expanded leaves under the chapters in the initial phase of flowering were collected and analyzed according to the sulfuric acid digestion method; b) number of achenes per chapter; (c) mass of one thousand achenes, in grams per plot; d) the achene pro- 
ductivities $\left(\mathrm{kg} \mathrm{ha}^{-1}\right)$ were calculated from the masses of the achenes in the test plot and were extrapolated to an area of one hectare.

To determine the water contents in the achenes, $200 \mathrm{~g}$ samples were used to obtain the corrected productivities at $11 \%$ moisture; and e) oil contents, as percentages. The oil extraction was carried out using hexane by a Soxhlet extractor for six hours. f) The oil productivities were determined from the oil contents in the achenes and the productivities of the achenes, and the values were corrected to $11 \%$ humidity. g) The economic dose of $\mathrm{N}$ for the productivity of sunflower achenes was determined according to Raij (1991) and Natale et al. (2011). The average price per $\mathrm{kg}$ of the achenes that were purchased by wholesalers in the 2016 and 2017 harvests was considered. The costs per $\mathrm{kg}$ of $\mathrm{N}$, whose source was urea $(45 \%$ $\mathrm{N}$ ), were US $\$ 0.88$ and US $\$ 1.03$ per $\mathrm{kg}$ of this element in the respective crops (2016 and 2017). At the maximum economic dose, the following equivalence relationship was used: one $\mathrm{kg}$ of applied $\mathrm{N} \mathrm{kg}^{-1}$ of marketed achenes was equal to US $\$ 0.88 / \mathrm{US} \$ 0.56=\mathrm{US} \$ 1.57$ and US $\$ 1.03$ / US $\$ 0.56=$ US $\$ 1.84$, respectively. A price of US $\$ 1.00$ corresponded to $\mathrm{R} \$ 3.59$ in the 2016 crop and to $\mathrm{R} \$ 3.23$ in the 2017 crop.

The doses for maximum economic efficiency (MEE) were calculated based on the derivative of the regression equation between the achene production and $\mathrm{N}$ doses applied, which thus made it equal to the exchange ratio, that is (Tartaglia et al., 2020):

The economic dose $\left(\mathrm{x}^{1}\right)$ was calculated by (Tartaglia et al., 2020):

The data were submitted to analyses of variance for each agricultural crop (2016 and 2017) by using the program Sisvar, version 5.6 (Ferreira, 2011). Subsequently, joint analysis was performed for the relevant characteristics by using the homogeneity of variances between the harvests (Pimentel Gomes, 2009).
Regression analyses were performed with the Table Curve 2D application, version 5.01 (Jandel Scientific, 1992). For the comparisons between the agricultural crops, Tukey's test was used with a 5\% [probability] significance level.

\section{Results and Discussion}

The significant interactions among the agricultural crops, $\mathrm{N}$ doses and cultivars were recorded for the number of achenes per chapter, achenes and oil yields, and a double interaction between the $\mathrm{N}$ doses and cultivars, between the $\mathrm{N}$ doses and agricultural crops for the $\mathrm{N}$ contents and oil contents in the achenes, and also between the cultivars and agricultural crops for the mass of one thousand achenes (Table 1).

The leaf $\mathrm{N}$ contents increased with the fertirrigated $\mathrm{N}$ rates, which were in a range that was considered to be adequate (e.g., 35 to $50 \mathrm{~g}$ of $\mathrm{N}$ $\mathrm{kg}^{-1}$ dry matter, according to Castro and Oliveira (2005)), for doses of 30 to $120 \mathrm{~kg} \mathrm{ha}^{-1}$ of $\mathrm{N}$ in the cultivars and agricultural crops (Figures $2 \mathrm{~A}$ and 2B). In the plants that did not receive $\mathrm{N}$ fertilization, the leaf contents were below ideal levels, which can be explained by the low organic matter contents present in the soil; the plants exhibited visual symptoms that are characteristic of $\mathrm{N} \mathrm{de}$ ficiency, such as decreases in plant development, uniform chlorosis in the leaf limbus in the basal leaves and senescence, and decreases in the sizes of the receptacles that affected the numbers and weights of the achenes.

The cultivars responded differently to the $\mathrm{N}$ doses but were similar in the agricultural crops in terms of the number of achenes per chapter (Figure 2C). At $\mathrm{N}$ doses of 74 and $106 \mathrm{~kg} \mathrm{ha}^{-1}$, the Multissol and BRS 122 cultivars reached maximum values of 473 and 533 achenes per chapter, respectively, with decreases occurring when higher $\mathrm{N}$ rates were fertigated, while the Aguará 06 and Altis 99 cultivars remained responsive to $\mathrm{N}$ in the 2016 harvest. 
Table 1. $\mathrm{F}$ values of the analysis of variance for the $\mathrm{N}$ contents in the diagnostic leaf (DL) $\mathrm{g} \mathrm{kg}^{-1}$, numbers of achenes per chapter (NAC), 1000-achne masses (M1000A) g, achene yields of (YA) $\mathrm{kg} \mathrm{ha}^{-1}$, oil yields (YO) $\mathrm{kg} \mathrm{ha}^{-1}$ and oil contents (OC) $\%$ from the production of sunflower cultivars that were fertigated with $\mathrm{N}$ doses in two agricultural crops in a Brazilian semiarid region. [it would be desirable to mention the units of the variables, mainly M1000A, YA, YO and OC]

\begin{tabular}{|c|c|c|c|c|c|c|c|}
\hline \multirow{2}{*}{ Sources of Variation } & \multirow{2}{*}{ DF } & \multicolumn{6}{|c|}{ F values } \\
\hline & & DL & $\mathrm{NAC}$ & M1000A & YA & YO & $\mathrm{OC}$ \\
\hline Blocks (Season) & 6 & $2.38^{n s}$ & $1.49^{n s}$ & $1.50^{n s}$ & $3.60^{n s}$ & $5.08^{n s}$ & $0.31^{n s}$ \\
\hline Seasons (S) & 1 & $9.15^{* *}$ & $6.15^{*}$ & $20.11 * *$ & $2.36^{n s}$ & $6.22 *$ & $8.89 * *$ \\
\hline Doses (D) & 4 & $215.04 * *$ & $26.90 * *$ & $13.39 * *$ & $53.00 * *$ & $60.97 * *$ & $1.12^{n s}$ \\
\hline$S \times D$ & 4 & $8.88^{* *}$ & $9.46^{* *}$ & $1.29^{n s}$ & $3.50^{*}$ & $3.18^{*}$ & $0.40^{*}$ \\
\hline Cultivars (C) & 3 & $1.87^{n s}$ & $22.17 * *$ & $3.81 * *$ & $16.07 * *$ & $16.95 * *$ & $14.10^{* *}$ \\
\hline $\mathrm{C} \times \mathrm{S}$ & 3 & $0.42^{n s}$ & $4.53 * *$ & $16.69 * *$ & $1.15^{n s}$ & $1.58^{n s}$ & $1.22^{n s}$ \\
\hline $\mathrm{C} \times \mathrm{D}$ & 12 & $3.56^{* *}$ & $1.35^{n s}$ & $1.10^{n s}$ & $1.92 *$ & $1.56^{n s}$ & $0.84^{*}$ \\
\hline $\mathrm{S} \times \mathrm{D} \times \mathrm{C}$ & 12 & $1.21^{n s}$ & $4.04 * *$ & $1.68^{n s}$ & $2.78 * *$ & $2.10^{*}$ & $0.72^{n s}$ \\
\hline C.V. $1(\%) \dagger$ & & 7.15 & 23.61 & 20.79 & 23.72 & 22.27 & 6.29 \\
\hline C.V. $2(\%) \dagger$ & & 7.61 & 24.56 & 20.69 & 23.17 & 26.25 & 9.86 \\
\hline Overall mean & & 42.2 & 508.22 & 45.78 & $1,115.43$ & 532.56 & 47.63 \\
\hline
\end{tabular}

${ }^{n s}$ : not significant at $5 \%$ probability by the $\mathrm{F}$ test; $* *$ : significant at $1 \%$ probability by the $\mathrm{F}$ and $*$ test: significant at $5 \%$ probability by the F test; DF: degrees of freedom; $\uparrow \mathrm{CV}$ : coefficient of variation. [as mentioned, it would be desirable to put the units for each variable, mainly M1000a, YA, YO and OC]

Similar results were obtained in 2017; for the Multissol and BRS 122 cultivars, an approximate $\mathrm{N}$ dose of $96 \mathrm{~kg} \mathrm{ha}^{-1}$ of and $\mathrm{N}$ content in the leaves of 37.8 and $41.3 \mathrm{~g} \mathrm{~kg} \mathrm{~g}^{-1}$ corresponded to the production of the maximum numbers of achenes per chapter of 454 and 473, respectively. The Aguará 06 and Altis 99 cultivars responded to an $\mathrm{N}$ dose of $120 \mathrm{~kg} \mathrm{ha}^{-1}$ by producing 941 and 733 achenes, which were equivalent to an increase of 614 and 413 achenes per chapter with the fertirrigated doses, respectively (Figure 2D).

There was a difference between the cultivars for the 1000-achene masses in the agricultural crops (Table 2).

The Aguará 06 cultivar produced larger 1000 -achenes masses between the harvests in the 2016 and 2017 harvests. The Multissol and BRS 122 cultivars produced larger masses but there were no differences between them. The Altis 99 cultivar exhibited no differences between the agricultural crops and maintained a stable mass of achenes.
The increases in the masses of one thousand achenes can be attributed to the functions of $\mathrm{N}$ in the metabolism of the reserve compounds in the seeds. The obtained results corroborate those of Santos et al. (2016), who studied the effect of $\mathrm{N}$ fertilization on sunflower production using the BRS 122 cultivar and reported a mass gain of $8.45 \%$ for each $20 \mathrm{~kg} \mathrm{ha}^{-1}$ of $\mathrm{N}$ applied. At the same time, Lobo, Grassi Filho and Coelho (2012) and Ahmad et al. (2018) obtained nitrogen fertilization results for the $\mathrm{H} 251$ hybrid and reported an increase of $23.8 \%$ for doses of 50 to $300 \mathrm{~kg} \mathrm{ha}^{-1}$ of $\mathrm{N}$ for the mass of 1000 achenes. Soares et al. (2016) also verified the linear response of nitrogen fertilization to the mass of one thousand achenes with a $100 \mathrm{~kg}$ dose of $\mathrm{N} \mathrm{ha}^{-1}$. In Schwerz et al. (2016) and Silva et al. (2017), the corresponding doses for greater achene masses were 100 and $120 \mathrm{~kg} \mathrm{ha}^{-1}$ of $\mathrm{N}$, respectively.

In addition to genetic factors, the 1000 -achene masses can be modified by environmental factors. In the 2017 harvest, the average temperature did not exceed $28^{\circ} \mathrm{C}$, the rainfall index was 

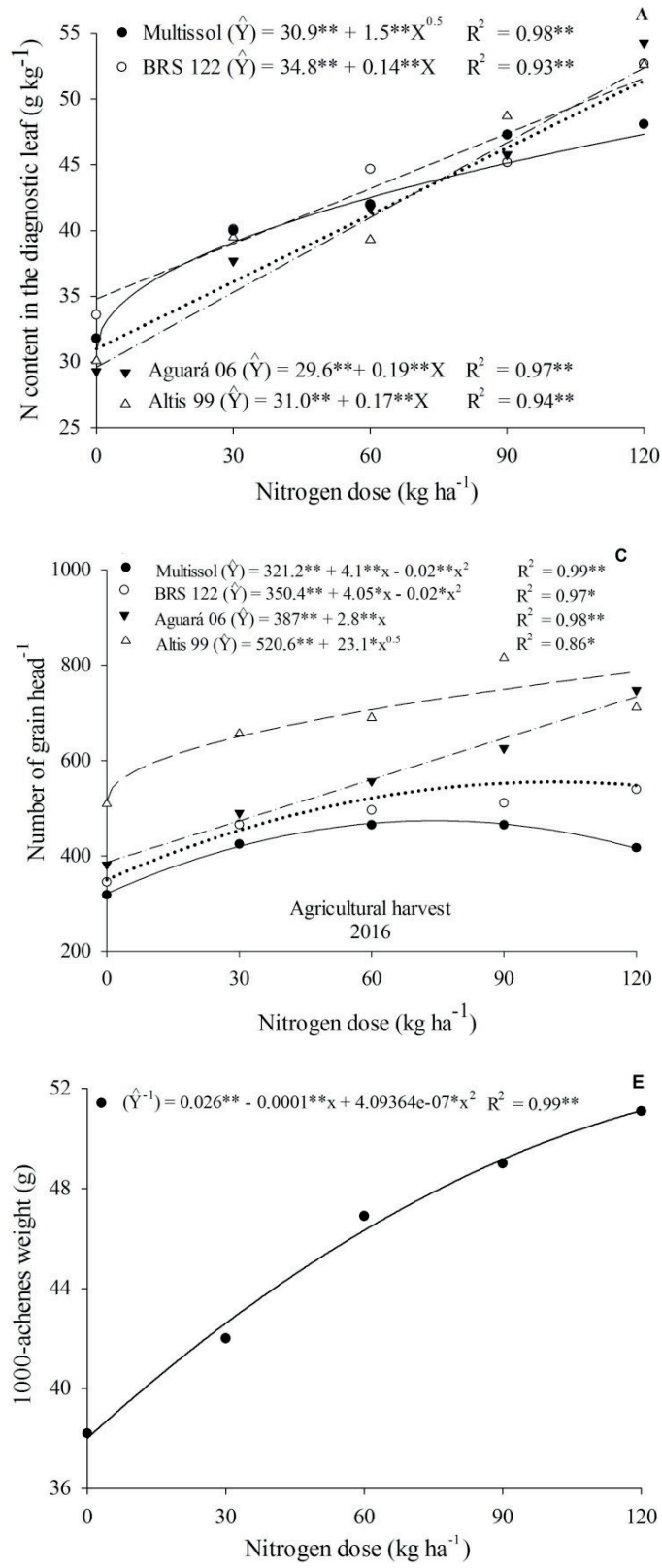
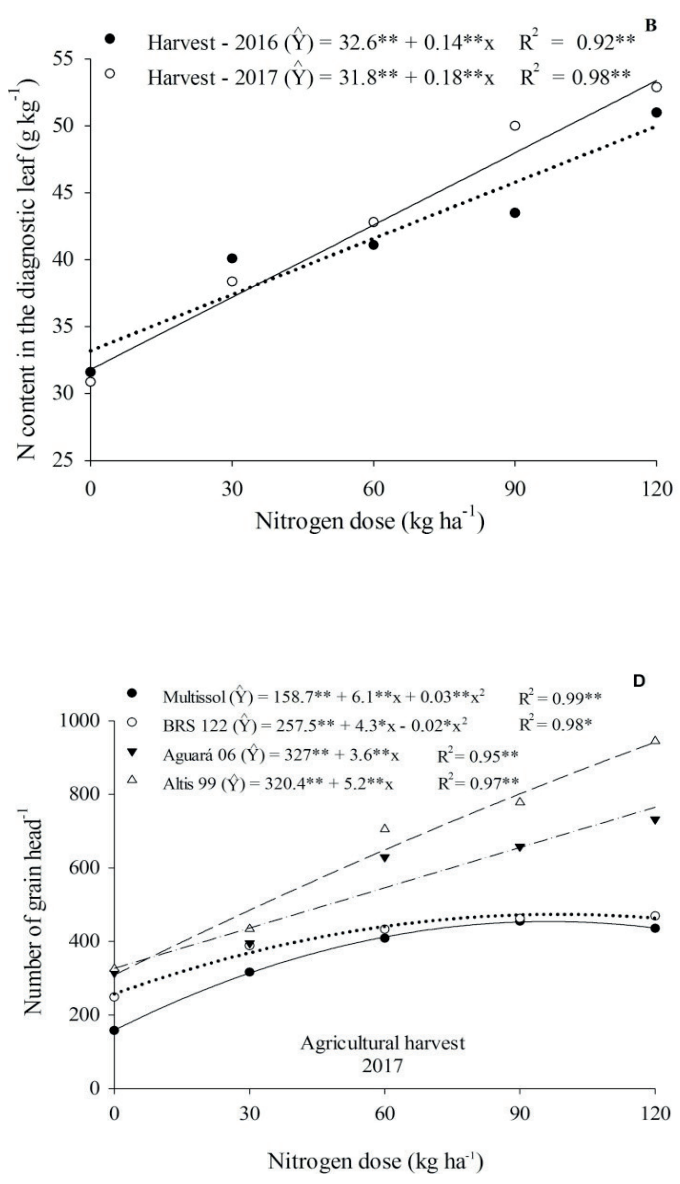

Figure 2. $\mathrm{N}$ contents in the diagnostic leaves by cultivar (A), agricultural crop (B), number of achenes per chapter for the agricultural crops of 2016 (C) and 2017 (D) and 1000 -achene masses (E) of the sunflower cultivars as a function of $\mathrm{N}$ doses in a Brazilian semiarid region.

Table 2. Mean values of 1000 -achene masses of the sunflower cultivars as a function of the partitioning of the interaction of the agricultural crops as a function of the cultivars in a Brazilian semiarid region.

\begin{tabular}{lrrrr}
\hline \multirow{2}{*}{ Agricultural crops } & \multicolumn{4}{c}{$\dagger$ Cultivars } \\
\cline { 2 - 5 } & \multicolumn{1}{c}{ Multissol } & \multicolumn{2}{c}{ BRS 122} & \multicolumn{2}{c}{ Aguará 06 } & Altis 99 \\
\hline & & \multicolumn{2}{c}{ Mass of 1000 achenes $(\mathrm{g})$} \\
2016 & $39.3 \mathrm{Bc}$ & $39.2 \mathrm{Bc}$ & $48.8 \mathrm{Aa}$ & $42.3 \mathrm{Ab}$ \\
2017 & $58.2 \mathrm{Aa}$ & $54.5 \mathrm{Aa}$ & $42.6 \mathrm{Bb}$ & $41.3 \mathrm{Ab}$ \\
\hline
\end{tabular}

$\dagger$ Means that are followed by the same uppercase letter in the columns and by lowercase letter in the rows do not differ statistically from each other by the Tukey test at $5 \%$ probability. 
$188.4 \mathrm{~mm}$, and the crop cycle and global solar radiation were regularly distributed at $20.7 \mathrm{MJ}$ $\mathrm{m}^{-2}$ day $^{-1}$ (Figure 1), which possibly influenced the duration of the entire crop cycle, which allowed greater accumulations and availability of reserves from photoassimilates and favored the increased achene mass, as was also reported in another study (Aguirrezábal et al., 2015).

The importance of $\mathrm{N}$ was also evident for the 1000-achene masses, which promoted a linear increase from a zero dose of fertirrigated N (38.4 g) and for a dose of $120 \mathrm{~kg} \mathrm{ha}^{-1}$ (51.6 g) (Figure $2 \mathrm{E}$ ), with an increase of $6.39 \%$ for each $30 \mathrm{~kg}$ ha $^{-1}$ of $\mathrm{N}$ applied.

The differential behavior of the numbers and masses of achenes of the studied cultivars are reflected in the productivity of the achenes. For the Multissol and BRS 122 cultivars, the maximum productivity reached occurred under conditions of fertigation at 81.8 and $86.6 \mathrm{~kg} \mathrm{ha}^{-1}$ of $\mathrm{N}$, which reached 1,331.0 and $1,421.5 \mathrm{~kg} \mathrm{ha}^{-1}$, respectively, but resulted in decreased productivity with the application of higher doses. For the Altis 99 and Aguará 06 cultivars, the productivities were linear with respect to the applied doses, and the ratios of $\mathrm{kg}$ of $\mathrm{N}$ applied per $\mathrm{kg}$ of achenes produced were 9.70 and 6.15 , respectively. Similarly, for the 2017 crop, N rates of 100.7 and $92.8 \mathrm{~kg} \mathrm{ha}^{-1}$ provided the maximum yields for the Multissol (1,385.9 $\left.\mathrm{kg} \mathrm{ha}^{-1}\right)$ and BRS $122(1,128.0 \mathrm{~kg}$ $\left.\mathrm{ha}^{-1}\right)$ achenes, respectively, while the Altis 99 and Aguará 06 cultivars responded to the highest $\mathrm{N}$ rates (Figure $3 \mathrm{~A}$ and $3 \mathrm{~B}$ ). The production of the cultivars with respect to the $\mathrm{N}$ fertilization requirements was similar in the agricultural crops. In 2016, different behaviors among the cultivars were observed, which were related to the $\mathrm{N}$ doses. At an $\mathrm{N}$ dose of $78 \mathrm{~kg}$ $\mathrm{ha}^{-1}$ and foliar $\mathrm{N}$ content of $32.5 \mathrm{~g} \mathrm{~kg}^{-1}$, the BRS 122 cultivar provided an estimated productivity of $633.30 \mathrm{~kg} \mathrm{ha}^{-1}$ and $120 \mathrm{~kg} \mathrm{ha}^{-1}$ of $\mathrm{N}$ with leaf $\mathrm{N}$ of $50 \mathrm{~g} \mathrm{~kg}^{-1}$, the Multissol (559) and Altis $99(880 \mathrm{~kg}$ $\mathrm{ha}^{-1}$ ) cultivars. For the Aguará 06 cultivar, at an $\mathrm{N}$ dose of $86.7 \mathrm{~kg} \mathrm{ha}^{-1}$ and foliar $\mathrm{N}$ content of $36.1 \mathrm{~g}$ $\mathrm{kg}^{-1}$, the productivity reached $713.6 \mathrm{~kg} \mathrm{ha}^{-1}$. In the 2017 harvest, $\mathrm{N}$ doses of 88.6 and $99.1 \mathrm{~kg} \mathrm{ha}^{-1}$ and leaf $\mathrm{N}$ contents of 36.9 and $41.3 \mathrm{~g} \mathrm{~kg}^{-1}$ corresponded to the yields of the BRS $122\left(561.40 \mathrm{~kg} \mathrm{ha}^{-1}\right)$ and Multissol (609.30 $\left.\mathrm{kg} \mathrm{ha}^{-1}\right)$ cultivars, respectively. The Altis 99 (746) and Aguará 06 (998.5 kg ha-1) cultivars had foliar contents of $50.2 \mathrm{~g} \mathrm{~kg}^{-1}$ of $\mathrm{N}$ at a dose of $120 \mathrm{~kg} \mathrm{ha}^{-1}$.

The oil yields were similar in the agricultural crops (Figures 3C and 3D). The achenes oil contents did not differ between the BRS 122, Aguará 06 and Altis 99 cultivars and provided 50, 48.2 and 47.7\%, respectively, which differed from the Multissol cultivar, with a value of $43.1 \%$. These results are in agreement with those observed by other authors, who also observed the effects of $\mathrm{N}$ doses on sunflower (Andrianasolo et al., 2016; Rocha et al., 2020).

The nitrogen fertilization recommendations for sunflower crops differ based on the regions of the country. Quaggio and Ungaro (1997) recommend an application of $50 \mathrm{~kg} \mathrm{ha}^{-1}$ of $\mathrm{N}$ for the state of São Paulo to reach yields between 1.5 and $2.8 \mathrm{t}$ $\mathrm{ha}^{-1}$ under rainfed conditions. Ribeiro et al. (1999) recommend $60 \mathrm{~kg} \mathrm{ha}^{-1}$ of $\mathrm{N}$ for the state of Minas Gerais, which aimed to reach yields of $1.5 \mathrm{t} \mathrm{ha}^{-1}$ under the same cultivation conditions. However, the research results provide different recommendations for sunflower cultivation under irrigated Brazilian semiarid conditions. Oliveira et al. (2012) obtained the best production response for the Embrapa cultivar 122/V2000 with an N dose of $80 \mathrm{~kg}$ $\mathrm{ha}^{-1}$ for irrigated crops. In Soares et al. (2016), an $\mathrm{N}$ dose of $100 \mathrm{~kg} \mathrm{ha}^{-1}$ produced higher yields. The interaction between genotypes and $\mathrm{N}$ availability in soil has often been observed as a factor that is responsible for productivity (Schwerz et al., 2016; Silva et al., 2017).

For the doses of maximum economic efficiency (MEE), 60.9 and $64.5 \mathrm{~kg} \mathrm{ha}^{-1}$ of $\mathrm{N}$ were obtained for the Multissol $\left(1,177.9 \mathrm{~kg} \mathrm{ha}^{-1}\right)$ and BRS 122 $\left(1,160.6 \mathrm{~kg} \mathrm{ha}^{-1}\right)$ cultivars in the 2016 harvest (Figure 4A). When we compared the productivity that was obtained from the MEE doses with the control, the use of $\mathrm{N}$ doses showed responses for the Multissol achenes $\left(14 \mathrm{~kg} \mathrm{ha}^{-1}\right)$ per kg ha ${ }^{-1}$ of $\mathrm{N}$ and for the BRS 

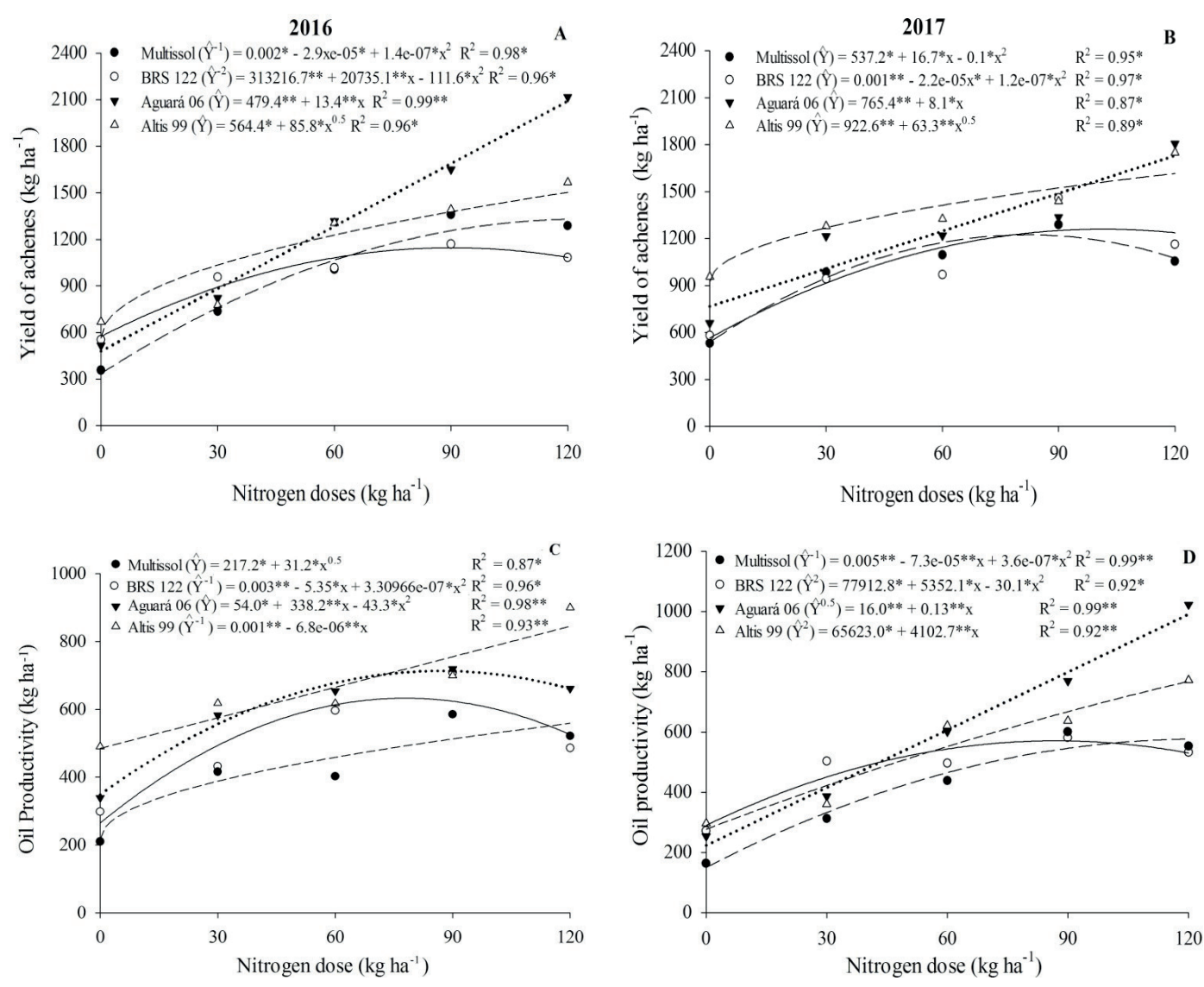

Figure 3. Achene productivities (A, B) and oil yields (C, D) of sunflower cultivars as a function of the $\mathrm{N}$ doses in an irrigated Brazilian semiarid region.

achenes of $122\left(8.9 \mathrm{~kg} \mathrm{~kg}^{-1}\right)$. In 2017, the doses for the MEE of the Multissol (75.1 kg ha-1 of N) and BRS $122\left(69.1 \mathrm{~kg} \mathrm{ha}^{-1}\right.$ of $\left.\mathrm{N}\right)$ cultivars were similar, with estimated yields of $1,227.3$ and $998.8 \mathrm{~kg} \mathrm{ha}^{-1}$ of achenes, respectively, which were equivalent to production responses per $\mathrm{kg}$ of applied $\mathrm{N}$ of 8.5 and $5.9 \mathrm{~kg}$ of achenes, respectively (Figure 4B).

When using the MEE doses, a reduction of approximately $25 \%$ from the maximum effective $\mathrm{N}$ doses for the cultivars occurred, and the yields that were obtained with the different economic doses were close to the maximum yields for the Multissol and BRS 122 cultivars, which reduced both costs and $\mathrm{N}$ losses to the environment.

The research data recommend doses above 80 $\mathrm{kg} \mathrm{ha}^{-1}$ of $\mathrm{N}$ for the most productive sunflower cultivars under semiarid irrigated conditions (Oliveira et al., 2012; Vasconcelos et al., 2015; Santos et al., 2016).

When using the MEE doses of $\mathrm{N}$ of the Multissol and BRS 122 cultivars, the expected incomes were obtained from the two agricultural crops. After subtracting the cost of $\mathrm{N}$ fertilizer in kilograms of the achenes in the 2016 harvest, the Multissol cultivar achieved a net revenue of US $\$ 421.73$ and for BRS 122, a net revenue of US $\$ 322.30$ was achieved. From this perspective, in 2017, the net revenue that was obtained from the Multisol cultivar with an MEE N dose was $75.1 \mathrm{~kg} \mathrm{ha}^{-1}$ (US \$ 349.88). For the BRS 122 cultivar, an $\mathrm{N}$ dose of 69.1 $\mathrm{kg} \mathrm{ha}^{-1}$ produced a net revenue of US \$252.47 ha ${ }^{-1}$. The results obtained agree with those Rasool et al. (2013) for semiarid conditions with light irrigation. 

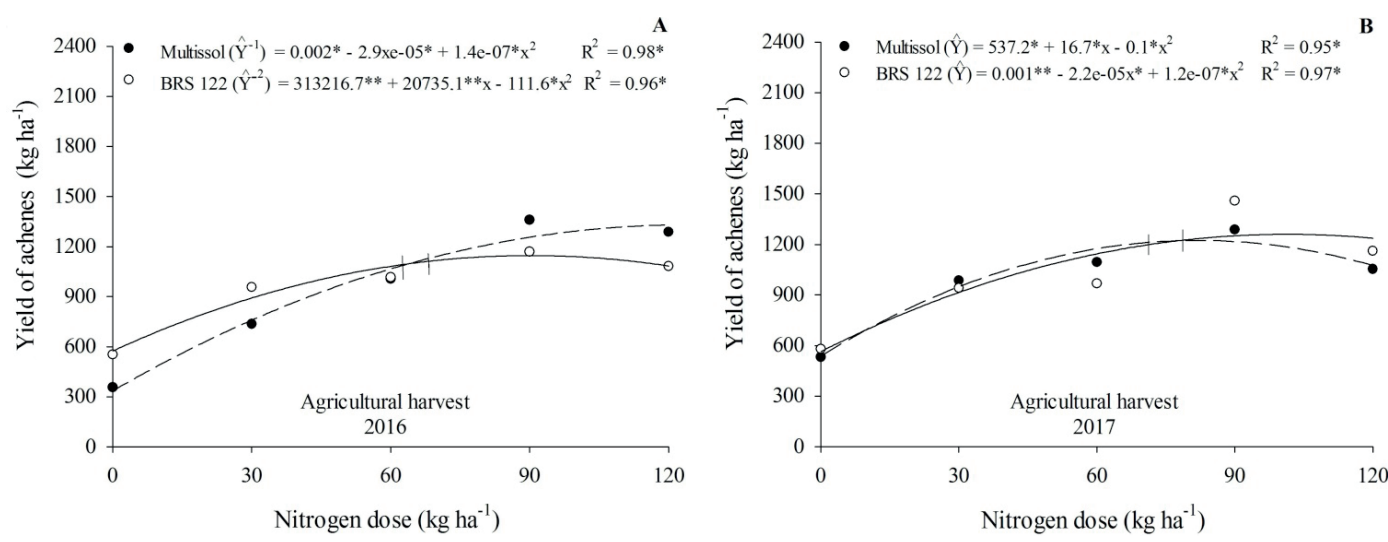

Figure 4. Achene productivities of sunflower cultivars as a function of the $\mathrm{N}$ doses of maximum economic efficiency, agricultural crop 2016 (A) and 2017 (B) in a Brazilian semiarid irrigated region.

The nitrogen doses positively influenced the number, mass, yield of achenes and oil, except for the oil contents of the sunflower cultivars, in the two agricultural crops.

The $\mathrm{N}$ doses for the maximum achene yields for the Multissol and BRS 122 cultivars were 81.8 and $86.6 \mathrm{~kg} \mathrm{ha}^{-1}$, respectively, and the maximum achene yields were obtained for the Altis 99 and Aguará 06 cultivars at a dose of $120 \mathrm{~kg} \mathrm{ha}^{-1}$ of N in the 2016 crop season. In 2017, the Multissol and BRS 122 cultivars received $\mathrm{N}$ doses of 100.7 and $92.8 \mathrm{~kg} \mathrm{ha}^{-1}$, respectively, and the Altis 99 and Aguará 06 cultivars each received $\mathrm{N}$ doses of 120 $\mathrm{kg} \mathrm{ha}^{-1}$. The maximum economic efficiencies for $\mathrm{N}$ were 60 and $70 \mathrm{~kg} \mathrm{ha}^{-1}$ for the Multissol and BRS 122 cultivars, respectively.

To obtain the maximum oil yields, the maximum $\mathrm{N}$ doses were 78.0 and $86.7 \mathrm{~kg} \mathrm{ha}^{-1}$ for the BRS 122 and Aguará 06 cultivars, respectively, and were $120 \mathrm{~kg}$ $\mathrm{ha}^{-1}$ for the Multissol and Altis 99 cultivars for the 2016 harvest. For 2017, the maximum oil yields for the BRS 122 and Multissol cultivars were obtained at $\mathrm{N}$ doses of 88.6 and $99.1 \mathrm{~kg} \mathrm{ha}^{-1}$, respectively, and the maximum oil yields for the Altis 99 and Aguará 06 cultivars were obtained at $\mathrm{N}$ doses of $120 \mathrm{~kg} \mathrm{ha}^{-1}$.

The Aguará 06 cultivar provided higher achene productivities and oil yields in the two agricultural crops.
It is concluded that the nitrogen doses positively influenced the numbers, masses, and yields of achenes and oil, except for the oil contents of the sunflower cultivars, in the two agricultural crops.

The $\mathrm{N}$ doses for the maximum achene yields for the Multissol and BRS 122 cultivars were 81.8 and $86.6 \mathrm{~kg} \mathrm{ha}^{-1}$, respectively, and were obtained for $\mathrm{N}$ doses of $120 \mathrm{~kg} \mathrm{ha}^{-1}$ for the Altis 99 and Aguará 06 cultivars in the 2016 crop season. In 2017, the Multissol and BRS 122 cultivars received $\mathrm{N}$ doses of 100.7 and $92.8 \mathrm{~kg} \mathrm{ha}^{-1}$, respectively, and the $\mathrm{N}$ doses for Altis 99 and Aguará 06 cultivars were each $120 \mathrm{~kg} \mathrm{ha}^{-1}$ of. The maximum economic efficiencies of $\mathrm{N}$ were 60 and $70 \mathrm{~kg} \mathrm{ha}^{-1}$ for the Multissol and BRS 122 cultivars, respectively.

For the maximum oil yields, $\mathrm{N}$ doses of 78.0 and $86.7 \mathrm{~kg} \mathrm{ha}^{-1}$ were provided to the BRS 122 and Aguará 06 cultivars, respectively, and were $120 \mathrm{~kg} \mathrm{ha}^{-1}$ of $\mathrm{N}$ for the Multissol and Altis 99 cultivars in the 2016 harvest. In 2017, the BRS 122 and Multissol cultivars received $\mathrm{N}$ doses of 88.6 and $99.1 \mathrm{~kg} \mathrm{ha}^{-1}$, respectively, and the Altis 99 and Aguará 06 cultivars received $\mathrm{N}$ doses of $120 \mathrm{~kg} \mathrm{ha}^{-1}$.

The Aguará 06 cultivar achieved higher achene productivities and oil yields in the two agricultural crops. 


\title{
Resumen
}

\begin{abstract}
A.R.E. de Souza, F. de L. Tartaglia, A.P. dos Santos, F.S. de Oliveira, M.G. dos Santos, F. Bezerra Neto², L.M. da Silveira, y A.P. Barros Júnior. 2021. Producción de aceite de girasol en respuesta a la fertilización con nitrógeno en condiciones semiáridas bajo riego. Int. J. Agric. Nat. Resour. 57-69. El girasol es una de las oleaginosas más importantes del mundo, cuyos aquenios son valorados en varias cadenas industriales, principalmente para la extracción y procesamiento de su aceite. Aunque existe alguna información en la literatura, los requerimientos de nitrógeno $(\mathrm{N})$ para el girasol en condiciones semiáridas bajo riego aún no están claros. El diseño experimental utilizó bloques al azar, con tratamientos en parcelas subdivididas con cuatro repeticiones durante dos temporadas agrícolas. Las dosis de $\mathrm{N}$ (por ejemplo, 0, 30, 60, 90 y $120 \mathrm{~kg}$ ha-1) se asignaron a las parcelas, y a los cuatro cultivares de girasol utilizados (por ejemplo, Aguará 06, Altis 99, Multissol y BRS 122), que se plantaron en las subparcelas. Las dosis de $\mathrm{N}$ para los máximos rendimientos de aquenio para los cultivares Multissol y BRS 122 fueron de 81,8 y $86,6 \mathrm{~kg}$ ha-1, respectivamente, mientras que las dosis de $\mathrm{N}$ de $120 \mathrm{~kg}$ ha-1 produjeron los máximos rendimientos de aquenio para los cultivares Altis 99 y Aguará 06 en la temporada de cultivo 2016. En 2017, los cultivares Multissol y BRS 122 recibieron dosis de $\mathrm{N}$ de 100,7 y $92,8 \mathrm{~kg}$ ha-1, respectivamente, y los cultivares Altis 99 y Aguará 06 recibieron una dosis de $\mathrm{N}$ de $120 \mathrm{~kg}$ ha- 1 cada uno. Las dosis de fertirrigación de máxima eficiencia económica de $\mathrm{N}$ fueron de 60 y $70 \mathrm{~kg}$ ha- 1 para los cultivares Multissol y BRS 122, respectivamente. Para los rendimientos de aceite, en la cosecha de 2016 se utilizaron las dosis máximas de $\mathrm{N}$ de 78,0 y 86,7 kg ha-1 para los cultivares BRS 122 y Aguará 06 y para los cultivares Multissol y Altis 99 con una dosis de N de $120 \mathrm{~kg}$ ha-1. En 2017, los cultivares BRS 122 y Multissol recibieron dosis de $\mathrm{N}$ de 88,6 y $99,1 \mathrm{~kg}$ ha-1, respectivamente, y los cultivares Altis 99 y Aguará 06 recibieron dosis de $\mathrm{N}$ de $120 \mathrm{~kg}$ ha- 1 . El uso de la fertirrigación permitió una mayor eficiencia de las dosis de $\mathrm{N}$ en los cultivares de girasol de la región semiárida.
\end{abstract}

Palabras clave: Biocombustibles, Helianthus annuus L., fertirrigación con nitrógeno, productividad aceite.

\section{References}

Aguirrezábal, L. Martre, P., Pereyra-Irujo, G., Echarte, M.M., \& Izquierdo, N. (2015). Improving grain quality: ecophysiological and modeling tools to develop management and breeding strategies. In V.O. Sadras \& D.F. Calderini (Eds.), Crop Physiology (Second Edition) (pp. 423-465). Academic Press.

Ahmad, M.I., Ali, A., He, L., Latif, A., Abbas, A., Ahmad, J., ... \& Mahmood, M.T. (2018). Nitrogen effects on sunflower growth: a review. International Journal of Biosciences, 12, 91-101.

Alves, L.S., Stark, E.M.L.M., Zonta, E., Fernandes, M.S., Santos, A.M., \& Souza, S.R. (2017). Dif- ferent nitrogen and boron levels influence the grain production and oil content of a sunflower. Acta Scientiarum. Agronomy, 39, 59-66.

Andrianasolo, F.N., Champolivier, L., Debaeke, P., \& Maury, P. (2016). Source and sink indicators for determining nitrogen, plant density and genotype effects on oil and protein contents in sunflower achenes. Field Crops Research, 192, 33-41.

Biscaro, G.A., Machado, J.R., Tosta, M.S., Mendonça, V., \& Soratto, R.P. (2008). Adubação nitrogenada em cobertura no girassol irrigado nas condições de Cassilândia-MS. Ciência e Agrotecnologia, 32, 1366-1373.

Castro, C., \& Leite, R.M.V.B.C. (2018). Main aspects of sunflower production in Brazil. Oilseeds 
and fats, Crops and Lipids, 25, 104-115.

Castro, C., \& Oliveira, F.A. (2005). Nutrição e adubação do girassol. In: Leite, R. M. V. B. C., Brighenti, A. M., \& Castro, C. (Eds). Girassol no Brasil. (pp. 317-373). Londrina.

Cavalcante Júnior, E.G., Medeiros, J.F., Melo, T.K., Espínola Sobrinho, J., Bristot, G., \& Almeida, B.M. (2013). Necessidade hídrica da cultura do girassol irrigado na chapada do apodi. Revista Brasileira de Engenharia Agricola e Ambiental, 17,261-267.

Demir, İ. (2020). Comparing The Performances of Sunflower Hybrids in Semi-Arid Condition. Türk Tarım ve Doğa Bilimleri Dergisi, 7, 1108-1115.

Eltarabily, M.G., Burke, J.M., \& Bali, K.M. (2019). Effect of deficit irrigation on nitrogen uptake of sunflower in the low desert region of California. Water, 11, 2340.

Espínola Sobrinho, J., Pereira, V.C., Oliveira, A.D., Santos, W.O., Silva, N.K.C., \& Maniçoba, R.M. (2011, 18-21 July). Climatologia da precipitação no município de Mossoró - RN. Período: 19002010 [Paper presentation]. XVII Congresso Brasileiro de Agrometeorologia, Guarapari, ES.

Feitosa, H.O., Lacerda, C.F., Marinho, A.B., Costa, R.N.T.A., Carvalho, C.M., \& Gheyi, H.R. (2016). Productivity and economic analysis of sunflower/maize crop rotation under different levels of salinity and nitrogen. African Journal of Agricultural Research, 11, 1999-2006.

Ferreira, D.F. (2011). Sisvar: a computer statistical analysis system. Ciência e Agrotecnologia, 35, 1039-1042.

Graham, C.J., \& Varco, J.J. (2017). The effects of stabilized urea and split-applied nitrogen on sunflower yield and oil content. American Journal of Plant Sciences, 8, 1842-1854.

Jandel Scientific. (1992). Table Curve 2D: curve fitting software. Corte Madera: Jandel Scientific, p. 280 .

Köppen, W. (1936). Das geographische system der klimat. Borntraeger Science Publishers.

Lazicki, P., \& Geisseler, D. (2016). Soil nitrate testing supports nitrogen management in irrigated annual crops. California Agriculture, 71, 90-95.

Li, W.P., Shi, H.B., Zhu, K., Zheng, Q., \& Xu, Z.
(2017). The quality of sunflower seed oil changes in response to nitrogen fertilizer. Agronomy Journal, 109, 2499-2507.

Lobo, T.F., Grassi Filho, H., \& Coelho, H.A. (2012). Efeito da adubação nitrogenada na produtividade do girassol. Cientifica, 40, 59-68.

Natale, W., Rozane, D.E., Prado, R.M., Romualdo, L.M., Souza, H.A., \& Hernandes, A. (2011). Dose econômica de calcário na produtividade de caramboleiras. Revista Brasileira de Fruticultura, 33, 1294-1299.

Oliveira, J.T.L., Chaves, L.H.G., Campos, V.B., Santos Júnior, J.A., \& Guedes Filho, D.H. (2012). Fitomassa de girassol cultivado sob adubação nitrogenada e níveis de água disponível no solo. Revista Brasileira de Agricultura Irrigada, 6, 23-32.

Pimentel Gomes, F. (2009). Curso de estatística experimental (15th ed.). FEALQ, Piracicaba.

Quaggio, J.A., \& Ungaro, M.R.G. (1997). Girassol. In: B.V. Raij, H. Cantarella, J.A. Quaggio, \& A.M.C. Furlani (Eds.) Recomendações de adubação e calagem para o Estado de São Paulo (p. 198). IAC-FUNDAG.

Raij, B.V. (1991). Fertilidade do solo e adubação. Potafos, Piracicaba.

Rasool, F., Hasan, B., Jahangir, I., Ali, T., \& Mubarak, T. (2013). Nutritional yield and economic responses of sunflower (Helianthus annuus L.) to integrated levels of nitrogen, sulphur and farmyard manure. Journal of Agricultural Sciences, $8,17-27$.

Ribeiro, A.C., Guimarães, P.T.G. \& Alvarez, V.H.V. (1999). Recomendações para o uso de corretivos e fertilizantes em Minas Gerais: 5a . Aproximação. Comissão de Fertilidade do solo do estado de Minas Gerais. CFSEMG, Viçosa, p. 159.

Rocha, J.G., Alves, L.S., Stark, E.M.L.M., Tavares, O.C.H., Fernandes, M.S., dos Santos, A.M., \& de Souza, S.R. (2020). Metabolic characterization and oil profile of sunflower cultivars cultivated with increasing nitrogen doses. Bioscience Journal, 36, 266-279.

Santos, J.B., Guedes Filho, D.H., Gheyi, H.R., Lima, G.S., \& Cavalcante, L.F. (2016). Irrigation with saline water and nitrogen in production compo- 
nents and yield of sunflower. Revista Caatinga, 29, 935-944.

Schultz, E., De Sutter, T., Sharma, L., Endres, G., Ashley, R., Bu, H., Markell, S., Kraklau, A., \& Franzen, D. (2018). Response of Sunflower to Nitrogen and Phosphorus in North Dakota. Agronomy Journal, 110, 685-695.

Schwerz, F., Caron, B.O., Elli, E.F., Oliveira, D.M., Monteiro, G.C., \& Souza, V.Q. (2016). Avaliação do efeito de doses e fontes de nitrogênio sobre variáveis morfológicas, interceptação de radiação e produtividade do girassol. Revista Ceres, 63, 380-386.

Silva, S., Cardoso, J.A.F., Oliveira, H., Nascimento, R., Guimarães, R.F.B., \& Leão, A.B. (2017). Growth and biomass of sunflower under different nitrogen levels and available water in the soil of a semi-arid region. Australian Journal of Crop Science, 11, 32-37.

Soares, L.E., Emerenciano Neto, V.J., Silva, G.G., Oliveira, E.M.M., Bezerra, M.G.S., Santos, T. J.A., \& Difante, G.S. (2016). Crescimento e produtividade do girassol sob doses de nitrogênio e fósforo. Revista Brasileira de Agropecuária Sustentável, 6, 19-25.

Soares, E.B., Barros Júnior, A.P., Albuquerque, J.R.T., Santos, M.G., Lins, H.A. \& Bezerra Neto,
F. (2020). Sunflower performance as a function of phosphate fertilization in semiarid conditions. Acta Scientiarum. Agronomy, 42, 1-9.

Souza, A.R.E., Souza, E.G.F., Tartaglia, F.L., dos SANTOS, A.P., Barros Júnior, A.P., da SILVEIRA, L.M., ... \& dos SANTOS, M.G. (2020). Economic indicators of nitrogen fertilization in sunflower cultivars. Bioscience Journal, 36, 1938-1950.

Taiz, L., Zeiger, E., Møller, I.M., \& Murphy, A. (2017). Fisiologia e Desenvolvimento Vegetal. Armed.

Tartaglia, F.L., Santos, A.P., Souza, A.R.E., Santos, M.G., Silveira, L.M., \& Barros Júnior, A.P. (2020). Economical nitrogen dose for production of irrigated naturally colored cotton in the semiarid region. Revista Brasileira de Engenharia Agrícola e Ambiental, 24, 783-789.

USDA, United States Department Of Agriculture. (2021). Oilseeds: World Markets and Trade. Retrieved from: https://apps.fas.usda.gov/psdonline/circulars/oilseeds.pdf>.

Vasconcelos, D.V., Azevedo, B.M., Fernandes, C.N.V., Pinto, O.R.O., Viana, T.V.A., \& Mesquita, J.B.R. (2015). Métodos de aplicação e doses de nitrogênio para a cultura do girassol. Irriga, $20,667-679$.

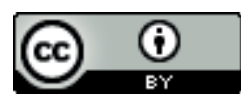

This work is licensed under a Creative Commons Attribution 4.0 International License. 